\title{
Resection of intraocular squamous cell carcinoma
}

\author{
D H Char, J Brooks Crawford, E L Howes Jr, A J Weinstein
}

\begin{abstract}
A patient with recurrent squamous cell carcinoma of the conjunctiva was referred with $20 / 20$ vision in an eye with obvious intraocular extension. A modified iridocyclochoroidectomy was performed and the tumour was removed. Three and a half years later the patient's vision is $20 / 30$ and there is no recurrence. This is the first case in which an eye has been successfully salvaged with documented intraocular squamous cell carcinoma of the conjunctiva.
\end{abstract}

Squamous cell carcinoma of the conjunctiva usually remains superficial, localised, and can be cured at that stage with resection and adjunctive cryotherapy or radiation. ${ }^{1-4}$ Rarely the tumour invades either into the orbit or the globe. Approximately 60 cases of intraocular invasion have been reported..$^{5-19}$ Usually this complication occurs in patients with either neglected or recurrent tumours. In a 60 year retrospective review from the Mayo Clinic there were two of 22 cases of invasive squamous cell carcinoma of the conjunctiva invaded into the globe ${ }^{8}$ In a series of 104 epithelial tumours reported by Irvine, one had intraocular invasion; similarly one of 27 invasive carcinomas reported from the Wilmer Institute had intraocular penetration..$^{16} 20$

Intraocular invasion from squamous cell carcinoma of the conjunctiva can have a number of clinical manifestations. We have noted it as an undiagnosed corneal perforation, anterior segment inflammation, a combined orbital and intraocular mass, a non-specific broad peripheral anterior synechiae, an apparently solitary intraocular mass, or a sheet of cells growing onto the iris surface, ${ }^{\prime}$ other presentations have included a necrotising scleritis. ${ }^{21}$ Nicholson and Herschler described a patient who presented with apparent anterior chamber inflammation in whom the

Ocular Oncology Unit, Department of Radiation Oncology, and the Francis I Proctor Foundation, University of California

D H Char

Eye Pathology Department, University of California

J Brookes Crawford

E L Howes

Private practice, New Mexico

A J Weinstein

Correspondence to:

D H Char, MD, Ocular

Oncology Unit, PO Box 0730

UCSF, San Francisco,

CA 94143, USA.

Accepted for publication 27 June 1991
Figure 1 External photograph demonstrates the appearance of the intraocular tumour. The patient had previously undergone a scleral graft. The intraocular tumour is visible between 7 and $9 o^{\prime}$ clock (arrow). correct diagnosis of squamous cell carcinoma was confirmed with aqueous paracentesis. ${ }^{\text {is }}$

The ocular prognosis for patients with intraocular invasion from conjunctival carcinoma has been dismal. All reported cases have required either enucleation or exenteration..$^{2-20} \mathrm{We}$ report a patient with recurrent squamous cell carcinoma that invaded the globe in whom we were able to successfully salvage both the eye and vision.

\section{Case report}

A 58-year-old female was referred with a recurrent right conjunctival squamous cell carcinoma with intraocular invasion. The patient was initially examined in January 1987 by her local ophthalmologist for an atypical area of solar damage at the right temporal limbus. In February 1987 this was resected and pathological examination revealed a squamous cell carcinoma. The tumour recurred 6 weeks later and a second resection was performed in April 1987. An en bloc excision of the tumour and the underlying $50 \%$ thickness sclera was performed. Adjunctive cryotherapy was delivered to the remaining scleral fibres and the edges of the resection. The area was closed primarily without a graft. The neoplasm recurred within 1 month in the same area and a third resection was performed in May 1987 with placement of a $10 \mathrm{~mm}$ diameter scleral allogeneic patch graft. Pathology sections demonstrated that all margins were clear.

Two months later in July 1987 intraocular invasion was noted (Fig 1) and the patient was referred to us for further management.

On our examination at that time the visual acuity was $20 / 20$ in each eye. The left anterior segment and fundus were unremarkable except for areas of lattice degeneration without retinal breaks. The intraocular pressure was $14 \mathrm{~mm} \mathrm{Hg}$ in the right eye and $16 \mathrm{~mm} \mathrm{Hg}$ in the left.

In the right eye there was a large scleral graft at the temporal limbus. The cornea was clear. The iris and ciliary body were involved with an amelanotic mass from 7 to 9 o'clock. There was no pupillary distortion. There was trace flare without cell in the anterior chamber. Examination of the right fundus with both scleral depression and three mirror contact lens examination was unremarkable.

Ultrasonography demonstrated a mass involving the lens and ciliary body. The tumour was approximately $7 \mathrm{~mm}$ thick on standardised A scan.

Various therapeutic options were discussed with the patient and her family and it was decided to proceed with a scleral resection and a modified iridocyclectomy. The area around the scleral graft was explored and obvious tumour extension along both surface and under the graft 


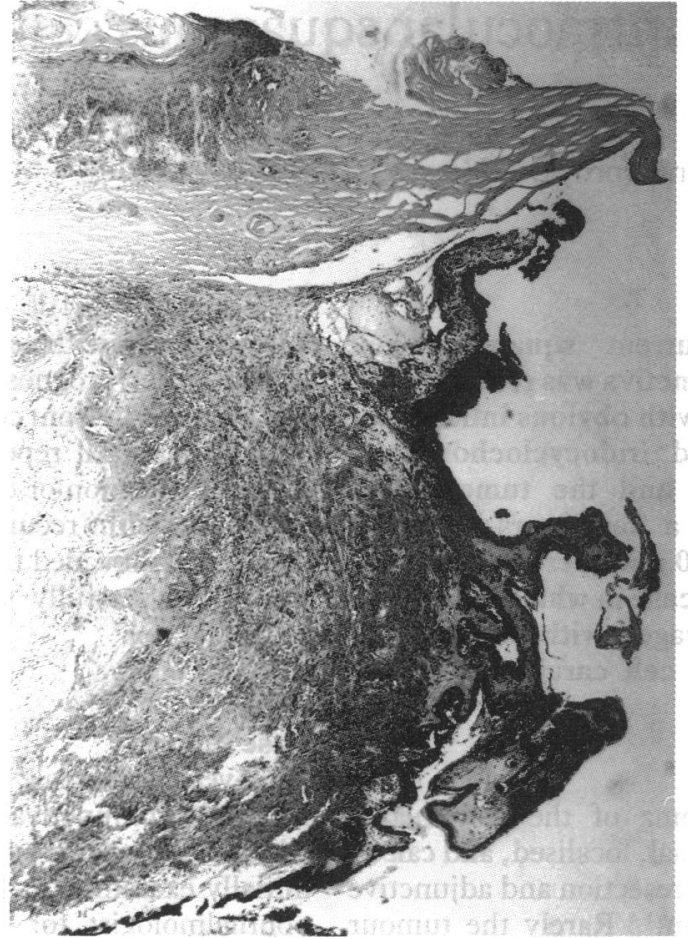

Figure 2A

Figure 2 (A)Low power photomicrograph of anterior portion of resected tissue $(H$ and $E, \times 10)$. (B) Higher power photomicrograph showing invasive squamous cell carcinoma arising from the conjunctival surface. Note the hyperkeratosis and keratosis on the surface of the conjunctiva, and the invasion of a scleral canal (arrow) $(H$ and $E, \times 40)$. (C) Higher power photomicrograph of the ciliary body invaded by squamous cell carcinoma, some of which has formed keratinising pearls ( $H$ and $E, \times 40)$.

was confirmed on frozen section. A large scleral resection approximately $17 \times 12 \mathrm{~mm}$ in diameter was performed and the contiguous iris, ciliary body, and choroid were removed en bloc. Frozen sections of the margins were clear. A free

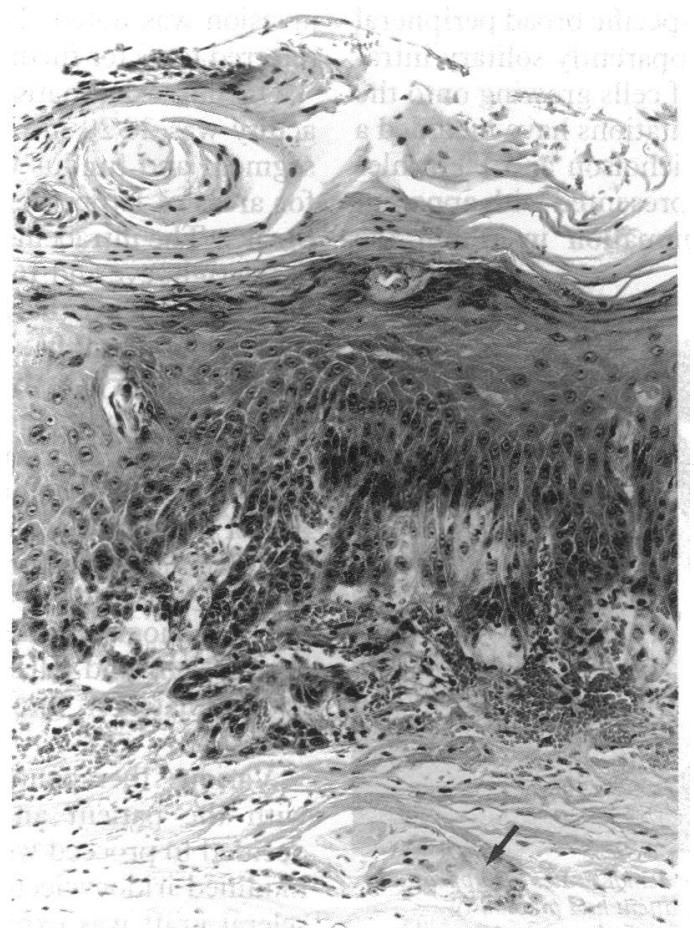

Figure $2 B$

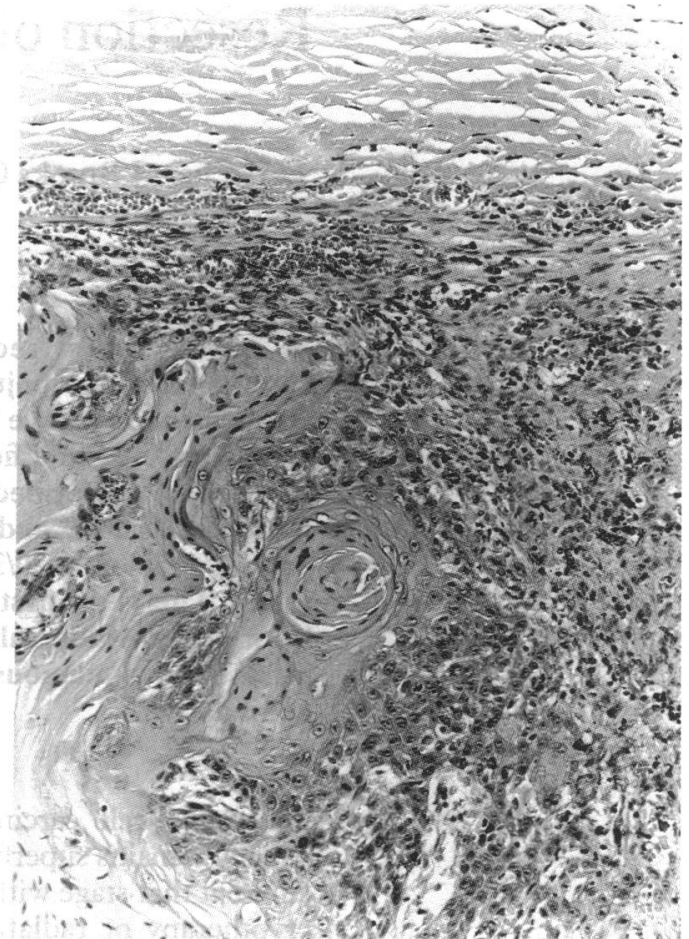

Figure 2C

allogeneic scleral graft was used to reconstruct the eye. Double freeze thaw adjunctive cryotherapy to adjacent sclera and conjunctiva was delivered in a standard manner. Microscopic examination of the resected tissue showed a keratinising squamous cell carcinoma arising from the conjunctiva and extending through scleral canals into the ciliary body (Figs $2 \mathrm{~A}$, $\mathrm{B}, \mathrm{C})$.

Postoperatively the patient slowly developed increasing lens opacity over the next year. She subsequently had an extracapsular cataract extraction and the implantation of an intraocular lens by her referring ophthalmologist in August 1989. A YAG laser capsulotomy was performed and on her last visit in August 1990 her visual acuity was 20/30. There was no evidence of tumour recurrence and the pressure was $14 \mathrm{~mm} \mathrm{Hg}$.

\section{Discussion}

There are at least three important risk factors for intraocular extension of squamous cell carcinoma of the conjunctiva, neglected malignancy, recurrent tumours, and histologic tumour type. ${ }^{91016}$ Our case had repeat excisions with apparently clear margins but eventually developed intraocular penetration. The disparity between the apparently clear surgical margins and recurrence emphasises the limitations of standard frozen section control of tumour margins. While that histological technique is quite accurate to delineate horizontal tumour spread, especially with a small surgical specimen, its efficacy for sampling the deep surface is poor. We have had one other conjunctival tumour patient with clear frozen section margins who developed a recurrence because of inapparent tumour at the deep surgical line. These limita- 
tions with frozen section technique have led us to use adjunctive cryotherapy both to the base as well as the horizontal resection lines in all cases.'

Intraocular penetration and metastases from squamous cell carcinomas of the conjunctiva are rare. ${ }^{1816}$ In most series fewer then $2 \%$ of cases have intraocular penetration, and only two patients in the United States have had documented metastatic disease. In 10 patients reported from Saudi Arabia with advanced disease seven had intraocular invasion.22 Mucoepidermoid and, possibly, spindle cell variants of squamous cell carcinoma are more locally aggressive and have a higher recurrence rate; each histological subtypes account for fewer than $5 \%$ of squamous cell carcinomas of the conjunctiva. ${ }^{91023}$

Very few surgeons have attempted to salvage an eye with intraocular penetration of squamous cell carcinoma of the conjunctiva; all previous cases have required either enucleation or exenteration. $\mathrm{Li}$ and co-workers reported two patients who had modified en bloc resections; however both had positive margins and were enucleated within 1 day and 1 week of the initial surgery. ${ }^{19}$ It is uncertain how many patients with intraocular proliferation of squamous cell carcinoma are candidates for a modified iridocyclochoroidectomy. We have examined five patients with intraocular extension from this tumour, and this was the only case in which we felt that this approach was indicated. Usually intraocular penetration by this malignancy is not amenable to local resection with ocular salvage because the tumour is too diffuse. Since 1903 a number of investigators have demonstrated that intraocular invasion is usually associated with diffuse spread in both the suprachoroidal space and the uvea. ${ }^{18}$ Often the tumour is sufficiently friable to seed cells into the anterior chamber and simulate inflammation. ${ }^{15}$ In some cases there is extensive orbital spread contiguous with the ocular involvement. In a minority of patients with apparently localised intraocular tumour a modified eyewall resection is a reasonable alternative.

This work was supported in part by NIH grant EYO 7504, and by unrestricted grants from That Man May See and Research to Prevent Blindness.

1 Char DH. Clinical ocular oncology. New York: ChurchillLivingstone, 1989: 63-87.

2 Kearsley JH, Fitchew RS, Taylor RG. Adjunctive radiotherapy with strontium- 90 in the treatment of conjunctiva squamous cell carcimona. Int $\mathcal{F}$ Radiat Oncol Biol Phys 1988; 14: 435 .

3 Peksayar G, Soyturk MK, Demiryont M. Long-term results of cryotherapy on malignant epithelial tumours of the conjunctiva. Am $\mathcal{F}$ Ophthalmol 1987; 107: 337.

4 Copeland RA Jr, Char DH. Conjunctival squamous cell carcinoma: limbal autograft reconstruction. Am $\mathcal{f}$ Ophthalmol 1990; 110: 412-5:

5 Stokes JJ. Intraocular extension of epibulbar squamous cell carcinoma of the limbus. Trans Am Acad Ophthalmol Otolaryngol 1955; 59: 143-6.

6 Zimmerman LE. Squamous cell carcinoma and related lesions of the bulbar conjunctiva. In: Boniuk M, ed. Ocular and of the bulbar conjunctiva. In: Boniuk M, ed. Ocult
adnexal tumors. St Louis: CV Mosby, 1964: 49-74.

7 Francois J, Hanssens M, German M. Epitheliomas perforantes du limbe et de la conjunctive bulbaire. Ann Oculist (Paris) 1967; 200: 505-21.

8 Erie JC, Campbell RJ, Liesegang TJ. Conjunctival and corneal intraepithelial and invasive neoplasia. Ophthalmology 1986 93: 176-83.

9 Brownstein S. Mucoepidermoid carcinoma of the conjunctiva with intraocular invasion. Ophthalmology 1981;88: 1226-30.

10 Gamel JW, Eiferman RA, Guibor P. Mucoepidermoid carcinoma of the conjunctiva. Arch Ophthalmol 1984; 102: $730-1$.

$11 \mathrm{Greer} \mathrm{CH}$. Limbal epithelioma with intraocular invasion. $\mathrm{BrF}$ Ophthalmol 1962; 46: 306-7.

12 Rasteiro A, Cunha-Vaz JG. Squamous cell carcinoma of the limbus with intraocular invasion. Ophthalmologica 1976; 172: 332-6.

13 Searl SS, Krigstein HJ, Albert DM, Grove AS Jr. Invasive squamous cell carcinoma with intraocular mucoepidermoid features. Arch Ophthalmol 1982; 100: 109-11.

14 Wexler SA, Wallow IHL. Squamous cell carcinoma of the conjunctiva presenting with intraocular extension. Arch Ophthalmol 1985; 103: 1175-7.

15 Nicholson DH, Herschler J. Intraocular extension of squamous cell carcinoma of the conjunctiva. Arch Ophthalmol 1977; 95: 843-6.

16 Iliff WJ, Marback R, Green WR. Invasive squamous cell carcinoma of the conjunctiva. Arch Ophthalmol 1975; 93: 119-22.

17 Dollfus MA. Un cas d'epithelioma perforant du limbe et considerations cliniques et therapeutiques sur les epitheliomas de las conjonctive bulbaire observes depuis 30 ans a la de las conjonctive bulbaire observes depuis 30 ans a la Fondation Curie

18 Duke-Elder S. System of ophthalmology. London: Henry Kimpton, vol. 8, 1965: 1165-75.

$19 \mathrm{Li} \mathrm{WW}$, Pettit TH, Zakka KA. Intraocular invasion by papillary squamous cell carcinoma of the conjunctiva. $A m \mathcal{F}$ Ophthalmol 1980; 90: 697-701.

20 Irvine AR Jr. Dyskeratotic epibulbar tumors of the limbus. Trans Am Ophthalmol Soc 1963; 61: 243-73.

21 Lindenmuth KA, Sugar A, Kincaid MC, Nelson CC, Comstock CP. Invasive squamous carcinoma of the conjunctiva presenting as necrotizing scleritis with scleral perforation and uveal prolapse. Surv Ophthalmol 1988; 33: 50-4.

22 Tabbara KF, Kersten R, Daouk N, Blodi FC. Metastatic squamous cell carcinoma of the conjunctiva. Ophthalmology squamous cell carcin

23 Grossniklaus HE, Green WR, Luckenbach $M$, Chan CC. Conjunctival lesions in adults. Cornea 1987; 6: 78-116. 